\title{
V \\ DO QUILOMBO ÀS FAVELAS: FACES DO RACISMO TERRITORIAL NA PRODUÇÃO DAS CIDADES*
}

\author{
Maria Helena Elpidio ${ }^{1}$
}

\section{INTRODUÇÃO}

A expressão "do quilombo à favela" muito utilizada nos estudos acadêmicos, literários e em conhecidos versos e prosas do universo cultural negro e periférico, expressa como modos de se produzir o espaço definem as vidas e as formas de produzir e se reproduzir em uma sociedade. A produção capitalista do espaço, que tem como base fundante a propriedade privada da terra e a transformação deste bem universal da humanidade, em mercadoria se apoia no racismo estrutural também nas formas de constituição dos espaços urbanos. Daí, lidamos com uma dura realidade cotidiana do povo negro no Brasil, onde o racismo se materializa também nos processos de produção e ocupação socioterritorial.

O texto busca evidenciar como este modo de produção capitalista do espaço incide diretamente em formas desiguais e desumanas de uma lógica genocida (nos termos de Adbias do Nascimento), onde a cor da pele define as formas de viver e ocupar os territórios e como o Estado, apoiado no racismo estrutural e institucional, reproduz e amplia a violência e o silenciamento do povo negro para a manutenção da hegemonia capitalista. Ora, se a produção do espaço revela as contradições do sistema capitalista e seu esgotamento, contra-

\footnotetext{
*DOI - 10.29388/978-65-86678-35-2-0-f.129-150

${ }^{1}$ Mulher negra, origem de Caratoria (morro da cidade de Vitória-ES), candomblecista, assistente social, professora do Departamento de Serviço Social e do Programa de Pós-graduação em Política Social da Universidade Federal do Espírito Santo (UFES), pós-doutoranda pela FSS/PPGSS/UFJF, doutora em Serviço Social pela Universidade do Estado do Rio de Janeiro (UERJ). Membro do Grupo de Estudos Octavio Ianni (UERJ) e do Núcleo de Estudos Interfaces (UFES). Presidente da ABEPSS (gestão 2017-2018). E-mail: lenaeabreu@gmail.com https://orcid.org/0000-0001-8243-542
} 
ditoriamente, são nesses espaços de maior repressão e imposição deste modelo destrutivo que se configuram formas de resistência e luta por novos quilombos.

\section{O RACISMO TERRITORIAL: QUILOMBOS E FAVELAS COMO ESPAÇOS PRODUZIDOS}

O modo de produção capitalista do espaço incide diretamente em formas desiguais e desumanas de uma lógica genocida, nos termos de Adbias do Nascimento (2016), onde a cor da pele define as formas de viver e ocupar os territórios e como o Estado, por meio do racismo institucional, reproduz e amplia a violência e as formas de silenciamento e marginalização do povo negro, bem como, a uma divisão racial do trabalho e do espaço. A este processo, considero que há na sociedade hodierna um processo avassalador de racismo socioterritorial, alimentado pela lógica capitalista de produção do espaço. Daí, para romper com os muros e barreiras da cidade do capital, torna-se imperativo, romper com o racismo e com o modo de produção capitalista.

A expressão "do quilombo à favela" muito utilizada nos estudos acadêmicos, literários e em conhecidos versos e prosas do universo cultural negro e periférico, marcado recentemente no samba enredo de 2018, da escola de samba "Unidos do Tuiuti" - Rio de Janeiro, expressa como modos de produzir o espaço se define historicamente, e com ele, formas de produzir e reproduzir a vida em uma sociedade, são marcados dialeticamente, pela forma de organizar e construir territórios a partir dos sujeitos sociais em movimento (ABREU, 2016).

Começamos com os quilombos, pois "nossos passos vêm de longe". Caracterizado por uma estrutura coletiva de uso e produção da terra, sem posses individuais e apropriação de excedentes. No quilombo, metaforicamente todos/as trabalham, se alimentam, dançam ao som dos tambores para saudar os seus deuses e deusas, protegem a natureza e produzem tudo o que é necessário para si e para a sua comunidade. As decisões são coletivas e o maior bem cultural está pautado da cosmogonia africana "Eu sou, porque nós somos"!

Segundo Gomes (2015), os quilombos e mocambos se formavam, via de regra, por escravos fugitivos de canaviais e engenhos do Nordeste e os primeiros registros instam de 1575 , considerando um mocambo no interior da 
Bahia. Já o mais conhecido, foi e continua sendo o quilombo de Palmares, que surgiu no final do século XVI, no território da capitania de Pernambuco, mais precisamente em uma região em que hoje está localizado o estado de Alagoas. $\mathrm{O}$ quilombo foi formado por escravos que tinham fugido de engenhos da região de Pernambuco e que escolheram a região da Serra da Barriga, na zona da mata de Alagoas.

O primeiro registro conhecido que faz menção ao Quilombo dos Palmares remonta a 1597, embora existam algumas teorias que sustentam que o quilombo já existia antes disso. A historiografia conta que o mesmo foi destruído em 1694 e seu líder, Zumbi, foi morto no ano seguinte em uma emboscada. No entanto, a história de Palmares resiste em outros moldes, sua experiência e legitimidade reconquistada pelo movimento negro o coloca como hoje como patrimônio histórico da América Latina.

Moura (1981, 2019), a despeito da historiografia branca e acadêmica sobre o papel dos negros na sociedade brasileira, mostra como Palmares se constituiu como força motriz econômica, cultural, sociológica e política de insurreição contra o regime escravista, pois foi sendo construído a partir da junção de mocambos, pequenos assentamentos de escravos fugidos, na divisa de Alagoas e Pernambuco (mas na época, tudo fazia parte da mesma capitania). No caso de Palmares, os mocambos formavam uma confederação quilombola que se estendia por um território razoavelmente vasto que incorporava além de negros escravizados fugitivos, alforriados, nascidos livres em Palmares, os indígenas, camponeses brancos sem terras e demais etnias e grupos oprimidos pelo regime colonial.

Outro destaque ao território de Palmares trata da organização política, tendo as mulheres, sacerdotes e sacerdotisas de diferentes cultos e tradições, bem como as pessoas mais velhas aquelas referências que possuíam papéis de destaque nas estruturas internas, devido à tradição africana e valorização da oralidade como memória e registro coletivo. Somente esta região chegou a ter cerca de 20 mil habitantes, sobre este aspecto o autor constata:

Transformou-se Palmares no mais sério obstáculo ao desenvolvimento da economia escravista da região. Como a região na época, era a mais importante para a prosperidade desse tipo de economia, podemos aquilatar 
a preocupação que Palmares representava para as autoridades da Metrópole. (MOURA, 2019, p. 196).

Ao relatar como eram retratados os quilombos por uma série de autores do período colonial, destacou

Esta forma de organização dava, como consequência, uma economia de abundância. É outro estudioso do assunto, Décio Freitas, quem a caracteriza da seguinte forma: "Faziam largo consumo de banana pacova, abundante na região. Criavam galinhas e suínos. Pescavam e caçavam. [...] E acrescentava mais: "É que nas comunidades negras reinava uma fartura que oferecia um vivo contraste com a perene miséria alimentar da população do litoral. A abundância da mão-de-obra, o trabalho cooperativo e a solidariedade social haviam aumentado extraordinariamente a produção. O superproduto social se tornara abundante. Depois de alimentada a população, atendidos os gastos coletivos e guardadas em celeiros as quantidades destinadas à épocas de más colheitas, guerras e festividades, ainda sobrava para trocar por produtos essenciais das povoações luso-brasileiras. (MOURA, 1981, p. 39-40)

É ilusório prever que em um modelo de cidade pautada pelo modo de produção do espaço na sociedade capitalista, haja um compasso possível de criação de igualdade na forma de uso, produção e ocupação dos territórios. Vale lembrar que o processo de colonização e posteriormente, a constituição da República, se faz em tempos históricos que caminham para permitir o processo de desenvolvimento da acumulação capitalista e assim como Palmares, outros quilombos que possuíam a mesma lógica e os maiores já caminhavam para estruturas próximas desta república quilombola. Obviamente, se tornaram alvo no caminho destrutivo das elites brasileiras e internacionais em diferentes tempos históricos, o que prevalece até o presente. (GOMES, 2015; MOURA, 2019)

Outro dado negado pela historiografia hegemônica corresponde ao poder de insurreição dos quilombos e mocambos, Moura (2019, p. 189) afirma que "[...] preferiram as liberdades entre as feras que a sujeição entre os homens". As forças militares dos quilombos se ergueram pela necessidade constante de proteção diante da negação da ordem colonial e à própria condição de escravização. A existência de grupos armados no interior dos quilombos era necessária, pois estavam em constante prontidão para defender a vida e as formas 
de produção que garantiriam a sobrevivência nestes territórios. Tais contingentes de defesa passaram a se organizar como exércitos, com estratégias e táticas desenvolvidas para fazer frente aos constantes ataques promovidos pela Metrópole e seus representantes.

Via de regra, os levantes e revoltas ocorridas no país que questionavam poderes instituídos que procuravam se erguer como forças de oposição e organização, tinham em suas bases, os grupos armados dos quilombos, como constam em registros das revoltas e insurreições urbanas como Revolta dos Búzios (dos Alfaiates/Conjuração baiana) - Bahia, 1798, Revolução Pernambucana Pernambuco, 1817, Revolta das Carrancas - Minas Gerais, 1833, Revolta dos Malês - Bahia, 1835, Balaiada - Maranhão, 1838-1841, Revolta de Manoel Congo - Rio de Janeiro, 1838, Revolta de Queimado - Queimado/ES, 1849*, A Greve Negra - Bahia, 1857, dentre outras (GOMES, 2015; MOURA, 1981)

Apagar memória desta construção social tem sido uma tarefa constate do Estado Brasileiro, pois fica evidente a ameaça que o movimento subjacente de recuperação destes princípios pode representar ao modelo destrutivo hegemônico capitalista, branco, machista e sexista.

Neste caso, em se tratando do sistema escravocrata da monarquia para o modelo liberal da república, advoga-se ao sujeito livre uma transposição de status formal, desvinculado de uma profunda mudança na estrutura patrimonialista, patriarcalista e fundiária do país. Daí, temos os traços de uma abolição inconclusa que impede a verdadeira transformação do escravizado em cidadão neste país (IANNI, 1972).

Neste processo, o Estado age como indutor de um simulacro republicano com crescimento de uma política eugenista de migração, branqueamento e reforço da lógica discriminatória onde negros permanecem como subumanos mediante teorias racialistas, que ainda hoje, buscam justificar a supremacia da raça branca/caucasiana sobre as demais (GOES, 2018). Tal processo evoca uma trajetória tenebrosa de violência, expropriações e explorações sucessivas, onde o Estado possui uma função primordial para o desenvolvimento e a manutenção do sistema capitalista.

Moura (2014) destacou que mesmo com o processo de abolição, não houve mudança qualitativa na estrutura da sociedade brasileira, o sociólogo afirmou que "O Brasil arcaico preservou os seus instrumentos de dominação, pres- 
tígio e exploração e o moderno foi absorvido pelas forças dinâmicas do imperialismo que também antecederam à Abolição na sua estratégia de dominação”. (MOURA, 2014, p. 152)

Neste sentido, as relações intrínsecas entre o racismo estrutural e o Estado capitalista dependente perpetram à população negra condições de vida em permanentes e persistentes desigualdades, que violam os princípios das estruturas que se reivindicam democráticas no mundo moderno. Assim, o mito da democracia racial segue causando uma cortina de fumaça, cercado de confusões e desorientações que limitam a compreensão dos fundamentos da dependência e dos profundos processos de exploração e ruptura com o arcaico projeto de nação, onde não cabem as aspirações e demandas de todos os segmentos que a compõe (FERNANDES, 2007)

Por isso, os inúmeros impasses atuais em torno da legitimidade dos quilombos no Brasil, que historicamente sofrem com as sucessivas intervenções do Estado para seu aniquilamento histórico e relevância cultural para o povo brasileiro, em especial, para a maior parcela da sua população que é negra ou de sua descendência. Embora a maioria esmagadora encontre-se na zona rural, também existem quilombos em áreas urbanas e peri-urbanas.

Nos termos do Decreto n. 4.887, de 2003, são as terras ocupadas por remanescentes das comunidades dos quilombos e utilizadas para a garantia de sua reprodução física, social, econômica e cultural. De acordo com o artigo $68^{\circ}$ do Ato das Disposições Constitucionais Transitórias da Constituição Federal de 1988, aos remanescentes das comunidades dos quilombos que estejam ocupando suas terras é reconhecida a propriedade definitiva, devendo o Estado emitirlhes os títulos respectivos. O uso comum da terra pelas comunidades é outra característica marcante desses territórios (IBGE, 2020).

Oficialmente no Brasil, considera-se agrupamento quilombola o conjunto de 15 ou mais indivíduos quilombolas em uma ou mais moradias contíguas espacialmente, que estabelecem vínculos familiares ou comunitários e pertencentes a Comunidades Remanescentes de Quilombos (CRQs), ou simplesmente Comunidades Quilombolas, que são grupos étnicoraciais, segundo critérios de autoatribuição, com trajetória histórica própria, dotados de relações territoriais específicas, com presunção de ancestralidade negra relacionada com a 
relacionada com a resistência à opressão historicamente sofrida, nos termos do Decreto n. 4.887, de 2003 (IBGE, 2020).

Os agrupamentos quilombolas são nomeados pelas comunidades locais de diversas formas, incluindo "comunidades negras rurais", "terras de preto", "terras de santo" "mocambo" etc. (IBGE, 2020).

Em 2019, foram mapeados cerca de 5.972 localidades quilombolas, estão espalhados em mais municípios: 1.672. Do total de localidades, 2.308 são agrupamentos, 3.260 têm outra identificação e 404 são territórios oficialmente reconhecidos. Mais da metade das localidades quilombolas (3.171) está no Nordeste, seguido do Sudeste (1.359). Só a Bahia tem 1.046. Logo depois, Minas Gerais aparece 1.021. Os dados populacionais ainda não podem ser constatados, pois apenas no censo 2020 que o item de identificação como quilombola será acrescido ao formulário (IBGE, 2020). Vale o registro que boa parte destes quilombos, ainda que reconhecidos sofrem constante pressão e repressão por parte do Estado e do capital, com constantes ameaças de despejos (reintegração de posse). Além da ausência de políticas efetivas que garantam a sobrevivência e a produção nestas comunidades tradicionais, nas quais incluo ainda as comunidades tradicionais de religiões de matriz africanas que também se organizam com bases comunais de habitação e posse coletiva dos bens da comunidade.

Uma vez expropriados da terra e diante do forte processo de urbanização modernizadora do país nos moldes do desenvolvimento capitalista periférico, temos as origens dos desastrosos resultados do crescimento das cidades voltadas a atender as demandas e voracidade do capital ao se apropriar do modelo de desenvolvimento urbano.

$\mathrm{Na}$ sociedade capitalista, como outros valores de uso, a terra e a moradia se convertem em mercadorias, com especificidades que merecem ser destacadas das demais, pois trata-se de mercadorias das mais caras, dentre os componentes necessários à reprodução do trabalho na vida privada e familiar dos trabalhadores. Tratando de forma específica a questão da moradia, Royer (2014) afirma

Que "trata-se, portanto, de uma mercadoria complexa, a comercialização envolve o capital específico de incorporação além dos capitais de construção e de financiamento, [...] de um bem imóvel que se valoriza a partir 
de atributos do entorno e à renda da terra, [...] tornando-a objeto de disputas acirradas" (ROVER, 2014, p. 07).

Cabe ressaltar que as políticas urbanas, dentre elas a habitação, são decorrentes do processo de conformação contraditória das cidades. O Estado exerce importante função no atendimento dos interesses do desenvolvimento produtivo capitalista, segundo exigências da industrialização e da urbanização. E quando necessário, atende a uma parte das demandas dos trabalhadores, principalmente, àquelas imprescindíveis a sua manutenção como força de trabalho e consumidores por exigência da dinâmica capitalista (FARAGE, 2012).

As expressões mais contundentes da produção capitalista do espaço em tempos de capitalismo financeiro ajudam a revelar os motivos reais das desigualdades sociais e raciais no Brasil e como estas se aprofundam no quadro perverso de organização/planejamento das cidades. Na sequência, alguns dados estatísticos do Instituto Brasileiro de Geografia e Estatística (IBGE) de 2010 oferecem tal dimensão.

Em uma série histórica que remonta este breve século XXI, retomando dados de 1993 e 2007, o percentual de residências que se encontravam em favelas ou semelhantes passou de 3,2\% para 3,6\%. Considerando a distribuição de acordo com o chefe da família, tem-se que 40,1\% dessas casas são chefiadas por homens negros, $26 \%$ por mulheres negras, $21,3 \%$ por homens brancos e $11,7 \%$ por mulheres brancas. De acordo com o estudo, essa distribuição mostra a predominância da população negra em favelas, o que reforça que as desigualdades socioterritoriais têm cor e raça no Brasil.

Outro ponto analisado, referente à condição de habitabilidade da população, é o adensamento excessivo, ou seja, o número muito grande de pessoas na residência. Os dados mostram o racismo pesa na perversa estatística da questão urbana novamente, pois apenas 3\% dos domicílios chefiados por brancos se encontram nessa situação, entre as famílias com chefes negros o percentual mais que dobra, chegando a 7\%. Também são mais comuns os domićlíos excessivamente habitados quando é o homem quem chefia: $5,1 \%$ contra $4,5 \%$ nas famílias chefiadas por mulheres. 
O Brasil em 2010 possuía 15.868 áreas ocupadas consideradas como subnormais $^{2}$ (ou mais usualmente, assentamentos precários), que somavam 169.170 hectares e comportavam 3.224.529 domicílios particulares permanentemente ocupados. A Região Sudeste foi a que apresentou a maioria de tais áreas do País (55,5\%), e também o maior percentual de domicílios nestas condições $(49,8 \%)$. O estudo indica ainda a concentração de ocupações significativas em áreas consideradas insalubres e degradantes, como palafitas sobre manguezais, canais pluviais e de esgoto, aterros sanitários, lixões, áreas de declives acentuados, de servidão da rede elétrica, gasodutos, rodovias, ferrovias, áreas de conservação ambiental, etc.

De um total populacional de 11.425.644 pessoas residentes em assentamentos precários, 59,3\% (6.780.071) estão concentradas nas Regiões Metropolitanas de São Paulo, Rio de Janeiro, Belém, Salvador e de Recife. O IBGE neste mesmo período, identificou ainda 6.329 favelas em todo o país. Segundo o levantamento, Rio de Janeiro, São Paulo, Minas Gerais e Espírito Santo concentram 49,8\% do total de casas nessas áreas (IBGE, 2013).

O avanço desta lógica perversa prevalece nos últimos levantamentos estatísticos, uma vez que em 2015, o déficit habitacional estimado correspondia a 6,355 milhões de domicílios, dos quais 5,572 milhões, ou 87,7\%, estão localizados nas áreas urbanas e 783 mil unidades encontram-se na área rural. Em contra partida, o grande montante dos domicílios vagos, de acordo com a Pnad 2015, o Brasil possuía 7,906 milhões de imóveis vagos, 80,3\% dos quais localizados em áreas urbanas e 19,7\% em áreas rurais. Desse total, 6,893 milhões es-

2 O Manual de Delimitação dos Setores do Censo 2010 classifica como aglomerado subnormal cada conjunto constituído de, no mínimo, 51 unidades habitacionais carentes, em sua maioria, de serviços públicos essenciais, ocupando ou tendo ocupado, até período recente, terreno de propriedade alheia (pública ou particular) e estando dispostas, em geral, de forma desordenada e densa. A identificação atende aos seguintes critérios:

a) Ocupação ilegal da terra, ou seja, construção em terrenos de propriedade alheia (pública ou particular) no momento atual ou em período recente (obtenção do título de propriedade do terreno há dez anos ou menos); e

b) Possuírem urbanização fora dos padrões vigentes (refletido por vias de circulação estreitas e de alinhamento irregular, lotes de tamanhos e formas desiguais e construções não regularizadas por órgãos públicos) ou precariedade na oferta de serviços públicos essenciais (abastecimento de água, esgotamento sanitário, coleta de lixo e fornecimento de energia elétrica) (IBGE, 2013). Vale registrar que se trata de uma nomenclatura oficial, que serve de parâmetro de avaliação das condições de moradia e por esse motivo, a utilizo neste texto. 
tão em condições de serem ocupados, 1,012 milhão estão em construção ou reforma. (FUNDAÇÃO JOÃO PINHEIRO, 2015). De acordo com este estudo, existiam neste mesmo ano, cerca de 7,225 milhões de domićlios carentes de, pelo menos, um tipo de serviço de infraestrutura, onde estes imóveis estão localizados? Qual o perfil dos moradores que sofrem as maiores privações no acesso à moradia digna e aos equipamentos urbanos?

De acordo com a estimativa, em 2019 haviam 5.127.747 milhões de domicílios ocupados em 13.151 mil aglomerados subnormais no país. Essas comunidades estavam localizadas em 734 municípios, em todos os estados do país, incluindo o Distrito Federal. Em 2010, havia 3.224.529 domicílios em 6.329 aglomerados subnormais, em 323 cidades, segundo o último Censo Demográfico $^{3}$. Este crescente corresponde ao período de agravo da crise de 2008 e do desmonte de políticas públicas e perdas de direitos sociais assistidos nos últimos anos frente ao avanço do conservadorismo e ultraliberalismo no Brasil.

Os dados não deixam dúvidas, pois é perceptível a diferença entre negros e brancos, especialmente no que diz respeito aos domicílios localizados em assentamentos subnormais, ou seja, favelas e assemelhados.

Uma mediação para a crítica a este processo é a compreensão do estatuto da propriedade privada capitalista e suas contradições, pois o ponto central para a questão da moradia, se estrutura na questão fundiária e na posse da terra. Esta é, certamente, a base da produção do espaço moldado ao desenvolvimento urbano capitalista ou, nos termos de Lefebvre, "A Cidade do Capital", que marca a efetivação do processo de produção e da reprodução da vida social considerando cada estágio do avanço das forças produtivas. Tendo em vista que é neste modelo de cidades "que a concentração de bens atinge seu grau mais elevado, que os costumes e as condições de vida do bom e velho tempo são radicalmente destruídos" (LEFEBVRE, 1999, p. 12).

O Brasil se constituiu em menos de um século como país predominantemente urbano, produzido em bases de transformações industriais de subordinação ao capital externo relativamente recentes, sem romper plenamente com o modelo patrimonialista rural de concentração de terras, de patriarcado e de con-

${ }^{3}$ Disponível em: < https://agenciabrasil.ebc.com.br/economia/noticia/2020-05/duas-em-cadatres-favelas-estao-a-menos-de-dois-quilometros >. Acesso em: ago. 2020. 
servadorismos não superados de sua base agrária desigual (FERNANDES, 2005, 2009).

Esta urbanização, assim como o processo republicano e democrático brasileiro, ocorre de forma totalmente descomprometida com a transformação das bases sociais e com o cumprimento da função social e fundiária nas cidades e no campo. Aprofundam-se, pois, as desigualdades socioterritoriais e raciais, cria-se uma dimensão particular das cidades no país que autoriza processos institucionais de expulsão, de segregação, de marginalização que se expressam no cotidiano de trabalhadores "desalojados e despejados" da cidade do capital.

Cotidianamente assiste-se à judicialização da questão urbana, em que a moradia, compreendida como um direito é encarada como caso de polícia devido à complexidade e aos interesses econômicos e políticos em torno da propriedade urbana. Resultado: a privatização desmedida dos espaços públicos. Repete-se cotidianamente as ações violentas de reintegração de posse em áreas urbanas como a de Pinheirinhos, São Paulo, no ano de 2012, da Aldeia Maracanã, no Rio de Janeiro, em 2013 e de Cais Estelita, Recife, em 2014 e relatos em Belo Horizonte e São Paulo em plena pandemia da Covid 19, em 2020.

Ainda sobre as atrocidades do racismo territorial, temos o exemplo trágico da pandemia da SARs-CoV-19, que em todos os estudos epidemiológicos apontam a maior propagação e letalidade em territórios aonde o vírus chegou antes do saneamento básico e que as condições de vida e moradia de trabalhadores, expõe à população negra os danos mais sérios provocados pela doença. Tais considerações são fundamentais para pensar como os impactos de uma história de racismo estrutural e institucional são agravadas mediante a crise do capital que ao longo das últimas décadas e governos, que contribuíram para a precarização e intensificado da exploração da força de trabalho, acompanhada de perdas sucessivas de direitos e proteções sociais com governos neoliberais e agora, ultraliberal e neoconservador capitaneadas pelo presidente Jair Bolsonaro.

O abandono histórico da questão urbana, que via de regra negligencia a questão racial, alimentada por um mito da democracia racial abre precedentes alarmantes para o seu agravamento na fase atual do capitalismo financeiro, que preconiza e estimula um modelo concorrencial entre as cidades, voltadas para o aperfeiçoamento gestionário de governança, apresentando territórios como vi- 
trines de oportunidades/atratividades para a especulação financeira e fundiária do grande capital (ABREU, 2016).

A tônica de apropriação do espaço é capacitar as cidades para concorrer entre si na captação e obtenção de recursos públicos e privados. Como exemplo evidente experimentado no Brasil e em outros países, tivemos a fábrica dos sonhos dos megaeventos, do Programa Minha Casa Minha Vida (PMCMV) e agora com o programa Casa Verde e Amarela. Como já dito, a moradia como mercadoria contém além de capitais fundiários, que permitem a especulação da terra urbana (o que nos ajuda a compreender facilmente a perda de sua função social) um volume expressivo de capitais fictícios. Na fase atual, pode-se ver que a habitação se converteu em iguaria apetitosa para o capital financeiro portador de juros, tendo em vista a mola propulsora de financiamentos habitacionais com recursos de contribuições sistemáticas dos trabalhadores formais. Como exemplo, o Fundo de Garantia por Tempo de Serviço (FGTS), recursos do BNDES e da CAIXA. No Brasil, historicamente estas são as principais fontes de composição do Fundo Nacional de Habitação de Interesse Social (FNHIS) (ROLNIK, 2015). É possível afirmar que os padrões de financiamento da política habitacional traduzem o movimento de transformações dos padrões de acumulação capitalista, onde o fundo público há anos se constitui como principal fonte de financiamento da política habitacional.

Nesta dinâmica, as expressões do racismo territorial são subsumidas em processos de higienização, pasteurização e uniformização de projetos de urbanização de áreas populares e degradadas, ampliação de serviços privados, além da forte ocupação militar para contenção e controle da vida social das áreas periféricas das cidades.

O fundo público funciona como um "balcão" ao gerar empréstimos, dividendos, passivos e títulos controladores de novas centralidades e nichos de produção, espaços que possam abrigar provisoriamente recursos fluídos e voláteis ao bel prazer das necessidades de rentabilidade do capital, fixadas de acordo com a submissão e/ou adaptação dos gestores públicos ao modelo gerencial capitalista engendrado na organização do Estado neoliberal e mais recentemente, ultraliberal.

Nota-se que a questão social, a questão racial, a questão fundiária no campo e na cidade caminham juntas, e por isso, ainda que intervenções urba- 
nísticas e de desenvolvimento territorial isoladas do conjunto das definições no âmbito da economia política se mostram historicamente incapazes de superar a chamada crise urbana. Pelo contrário, esta tende a se agravar.

A população favelizada representa cerca de $78 \%$ dos habitantes urbanos em países menos desenvolvidos e corresponde a um terço da população urbana mundial. Apesar de a maior incidência deste fenômeno ocorrer em países do hemisfério sul e parte da Ásia (principalmente na China e na Índia), observa-se o crescimento da favelização nos grandes centros urbanos em países centrais do capitalismo (ROLNIK, 2015). É fato evidente que em países afrodiaspóricos e no território africano a população negra constrói suas moradias de forma adensada em espaços urbanos precários, denominados mais popularmente no Brasil, como favelas (mas que tem diferentes denominações a depender da cultura local). A autora salienta que a "mercantilização da moradia, bem como o uso crescente da habitação como ativo integrado a um mercado financeiro globalizado, afetou profundamente o exercício do direito à moradia adequada pelo mundo”. (ROLNIK, 2015, p. 32)

Considerando aspectos das favelas, por mais que estas possuam formas de riquezas essenciais resguardadas em seus domínios territoriais (que são as pessoas, a cultura e ancestralidade do povo negro que nelas habitam), foi construída a partir de uma lógica perversa, da produção capitalista do espaço, que tem como base fundante a propriedade privada da terra e a transformação deste bem universal da humanidade, em mercadoria. (FARAGE, 2012)

Daí, lidamos hoje com uma dura realidade cotidiana do povo negro no Brasil, onde o racismo se materializa também nos processos de produção e ocupação socioterritorial. Carolina Maria de Jesus, em seu Quarto de Despejo: diários de uma favelada, escreveu em 1968 a denúncia:

Quando estou na cidade tenho a impressão que estou na sala de visita com seus lustres de cristais, seus tapetas de viludo, almofadas de sitim(sic). E quando estou na favela tenho a impressão que sou um objeto fora de uso, digno de estar num quarto de despejo. (JESUS, 2005, p. 33) 


\section{A CIDADE CAPITALISTA ALIMENTA O RACISMO SOCIOTER- RITORIAL: O PERIGO NÃO MORA NO BECO, MORA NO ASFAL- TO.}

Quando a rebeldia quilombola e periférica das favelas, produtoras de vida se choca com a falsa passividade liberal e o cinismo fascista que na crise atual se materializam no ultraliberalismo como referência para um projeto de nação que segue seu genocídio, massacrando negros e negras, com o seu chão repleto de sangue pisado desde as pedras dos cais até o corpo arrastado no camburão e metralhado em via pública, é que se evidencia o esgotamento do projeto de democracia e do Direito à Cidade.

$\mathrm{Na}$ lógica da cidade que tenta expurgar a favela, nota-se que não vem dos becos as nossas principais ameaças. Para que tenhamos uma outra sociabilidade onde se possa circular livremente, é imperativo a construção de processos radicais de capazes de reconstruir os espaços roubados pelo capital, alimentado pelo ódio racista e fascista que segrega e marginaliza corpos e territórios em todos cantos urbanos e rurais deste país.

Mais do que os números que elencamos quando tratamos do racismo e sua face institucional, trata-se de vidas humanas banalizadas pela lógica ultraliberal que coloca o mercado e os lucros acima de tudo e de todos, balizados ainda por uma supremacia que procura recuperar um nacionalismo enviesado com slogan "Brasil acima de tudo, Deus acima de todos!" que embala um violento processo de dilapidação da coisa pública por parte do presidente Jair Bolsonaro desde o início de seu governo, em 2019.

Falar em luta antirracista e anticapitalista, passa pela derrota do projeto neoconservador que assola o país e exige uma profunda transformação na estrutura fundiária e posse da terra no campo e nas cidades, para que possamos pensar em construir um novo modo de produção e dialeticamente de (re)produção social. Neste sentido, quilombo e favela se opõem radicalmente aos modelos privatistas da cidade do capital de apropriação da terra e dos seus territórios.

Mais do que mostrar as disparidades nas condições habitacionais que geralmente são exploradas nos estudos sobre territórios, temos a intenção de apontar como as bases do racismo no Brasil, historicamente impedem a supera- 
ção das desigualdades por meio de um conjunto de contrarreformas que direcionam indubitavelmente às ações para a posse privada da moradia e concentração de terras e riquezas voltadas exclusivamente para a ampliação das formas de expropriação e exploração que sustentam o modo de produção capitalista e suas formas destrutivas do meio ambiente e da humanidade.

A barbárie da privatização da cidade do capital revela historicamente o abismo social e as profundas desigualdades de classe no acesso e usufruto à moradia digna, ao ambiente salubre, à mobilidade e à produção. As desigualdades e o racismo socioterritorial são inerentes ao modo de produção do espaço no capitalismo, que tem na posse da terra, um dos seus pilares e se aprofunda na medida em que todas as coisas se convertem em mercadoria. A consolidação do modelo especulativo, segregador e privatizante é dialeticamente racista desde as origens do processo de diáspora, escravização e inserção negra na formação social brasileira.

Em se tratando dos lugares e territórios forçadamente destinados ao povo negro pelas elites dominantes, vimos que a questão territorial é estruturante pela ausência da posse da terra, combinadas à perversa superexploração dos territórios afrodiaspóricos, via de regra, frutos das invasões coloniais e do imperialismo. Neste sentido, há uma relação dialética das determinações sociais que unificam racismo e capitalismo, por isso a necessidade da apreensão do debate que não separa raça e classe, uma vez que se encontra no cerne da questão o Trabalho como mediação imprescindível à superação da sociedade de classes.

Por isso, o território se encontra como alvo constante de disputas, pois o seu desenho se dá a partir de mediações relacionadas ao modo no qual os trabalhadores/as produzem riqueza (que no caso do modo de produção capitalista, dá origem à miséria, conforme lei geral da acumulação, apresentada em "O Capital”, de Karl Marx).

O resultado deste processo promoveu uma acentuada segregação espacial nas cidades brasileiras desde metade do século XX, se estendendo até os dias atuais. Resultou ainda, na proliferação das favelas, que se constituíram o primeiro alvo do governo sobre a política habitacional na chamada Nova República, considerando a questão da habitação como mero déficit e resultado de uma crise habitacional agravada pelo processo de urbanização acelerado, tendo como foco, o controle e a coerção das classes tidas como perigosas. 
Os conjuntos habitacionais criados para o reassentamento dos moradores de favelas (muitas vezes por meio de remoções violentas) eram distantes dos locais de trabalho e do acesso ao conjunto de estruturas urbanas e sociais, além de demandarem novos custos da cidade regulada, como água, luz, etc, e, é claro, o ônus das prestações, que certamente estavam acima daquilo que este contingente de famílias poderia pagar. Assim, a política habitacional brasileira vive a em constante crise expressa por elevados índices de inadimplência e gentrificação ${ }^{4}$.

Este modo de interpretação expressa a materialização da concepção privatista que se tem do espaço urbano, longe da dimensão de universalidade e acesso coletivo aos bens e serviços produzidos socialmente.

Sob outra face, o acesso à moradia quando subsidiada por políticas de governo - com o endividamento das famílias direto pelas prestações ou indireto pelos novos encargos, urbanos -, resvala diretamente na esfera de lucratividade das empresas construtoras. Além de explorar mais-valia no processo direto de construção de moradias e especulação imobiliária, recebem uma fatia do fundo público para execução de obras caras, mal acabadas, sendo ainda um poderoso canal de desvio de recursos por corrupção. As maiores empresas do setor, são as mesmas que acumulam as listas de financiamentos ilícitos de campanhas políticas e pagamentos de propina para obtenção de vantagens e lucros incalculáveis no país.

Neste processo histórico repleto de determinações sócio-históricas, formaram-se senzalas, cortiços, "barracões de zinco pendurados no morro", palafitas, barracas de lona e de papelão. Se erguem "Cidades de Deus, Coroadinhos, Sol Nascente, Brasílias Teimosas, Abolições, Casas Amarelas, Marés, Pa-

\footnotetext{
${ }^{4}$ Processo desencadeado, via de regra, por processos de urbanização na lógica da cidade capitalista e/ou com a criação de infraestruturas urbanas que incidem na criação de custos mais elevados da terra e dos serviços urbanos em ocupações já consolidadas, que leva trabalhadores a se deslocarem voluntária ou involuntariamente para novos territórios desprovidos de infraestruturas adequadas de moradia e geralmente, mais distantes de espaços centrais nas cidades. Exemplos marcantes deste processo estão na história da política urbana brasileira como a construção da Cidade de Deus, no Rio de Janeiro e ainda com todo processo recente em várias capitais envolvendo a realização dos megaeventos, como a Copa do Mundo de 2014 e as Olímpiadas de 2016, bem como os super projetos de infraestrutura do setor energético, como as usinas de Belo Monte, Santo Antônio e Jirau, no norte do Brasil.
} 
raisólis, Pinheirinhos" como expressão territorial marcada pela voracidade destrutiva do modelo capitalista de produzir o espaço desigual.

Acordar no primeiro de maio de 2018 e ver um arranha céu de papelão se desmanchando em fogo no Centro da maior metrópole da América Latina é a representação do esgotamento do modelo de cidades que nada atende à classe que a constrói e a ocupa como ato legítimo. São milhares de vidas e de casas levadas nas águas ou por terras nos morros de Recife, Salvador, Niterói ou Pará. Pessoas que para se deslocar suportam reedições de carros de boi em paus-dearara, barcaças e trens da supervia.

O racismo territorial também deixa suas marcas por meio da ação violenta do Estado. A criação de projetos inspirados nas Unidades de Polícia Pacificadora (UPP), a invasão do exército nas favelas do Rio de Janeiro, a presença intimidadora e violenta da polícia e de milícias que se espraiam em diversos territórios são parte do nítido movimento de contenção do povo negro, seja violência que intimida, pela presença ostensiva ou pelo extermínio, o objetivo é de provocar o silêncio! Vale lembrar, como já citado, que a cada 23 minutos morre um jovem negro nas periferias, as chacinas que reeditam os pelourinhos e o caso emblemático do assassinato da vereadora Marielle Franco e Anderson, em abril de 2018, têm como traço comum: o lugar de origem das vítimas.

Novos negreiros surgem neste contexto paralelo às favelas. É quando jovens negros/as perdem a suposta "liberdade", o sistema reedita a senzala, que é o cárcere. Um novo território de segregação perverso que é habitado predominantemente por negros e suas famílias. Tais lugares ganham a objetivação de uma naturalização que não podem ser internalizadas, dentro e fora do Serviço Social, como se o "lugar" dos negros, tenha como marcas o lugar da violência, da pobreza e da criminalização. Romper as barreiras da segregação socioterritorial implica derrubar o modelo social que a produz. Superar o racismo e o capitalismo está no centro do processo.

A partir deste elemento é possível constatar o potencial mobilizador a partir da apropriação crítica da análise do território a partir da produção do espaço, uma vez que os elementos aqui arrolados expõem evidentemente as contradições deste sistema. 


\section{PARA TERMINAR: UM FUTURO SEM CERCAS E SEM COR- RENTES}

Notamos que o debate do racismo estrutural e institucional presente nas formas de ocupação dos territórios, contribuem ainda para decifrar o debate da questão urbana e da questão social. Apoiamo-nos em Engels (2013), ao travar um debate valioso sobre a "Questão da Habitação" diante das propostas dos conservadores e reformistas burgueses para resolver o crescente problema do crescimento das cidades e a situação de pauperização dos trabalhadores agravados pela ausência de condições dignas de moradia. $\mathrm{O}$ autor, nos idos de 1872, já indicava que não se tratava de um problema a ser resolvido com medidas paliativas, pois está intimamente ligado ao modo de produção capitalista e à sua reprodução no modelo de ocupação e apropriação das cidades. Por isso, não pode ser resolvido no âmbito de propostas reformistas. Assevera ainda:

E, enquanto o modo de produção capitalista existir, será disparate pretender resolver isoladamente a questão da habitação ou qualquer outra questão social que diga respeito à sorte dos operários. A solução reside, sim, na abolição do modo de produção capitalista, na apropriação pela classe operária de todos os meios de vida e de trabalho (Idem, p. 7374).

Duas formas extremas de urbanização na cidade do capital tratam de esvaziar a dimensão da vida pública e da sociabilidade pautadas na convivência coletiva, pasteurizando a dimensão da vida cotidiana. A primeira trata da urbanização de favelas ou áreas tidas como degradadas, cuja marca é de introdução de um modelo de padronização do urbano em relação à organização e integração social. Em outro extremo, o modelo de "cidade de muros" que privilegia os condomínios fechados de luxo, objeto de desejo de parte da população mais abastada, cuja formatação nega o espaço e a vida pública e reforça o niilismo social (ABREU, 2016). Em ambas prevalece a relação com o promissor mercado de serviços urbanos fortemente privatizados.

Não obstante a esta realidade, com o acirramento das expressões da questão racial e da social, nos últimos anos contra as relações de exploração, opressões e expropriações servem como combustível para os movimentos de 
resistência com bandeiras e lutas por garantias democráticas e defesa de direitos. Por isso, a insurgência dos movimentos urbanos e rurais, de trabalhadores organizados precisam ser marcadas pela presença radical da luta anticapitalista, antirracista e antimachista/sexista (incluindo todas as lutas em torno das formas de opressão e exploração).

Retomo ao aprendizado dos quilombos e das favelas, onde a urgência da retomada da sociabilidade que não separa ser humano da natureza, próprios da cosmogonia africana, para que tantas Carolinas e Marias não continuem a ser despejadas. A população negra em movimento como classe, é uma potência nesta sociedade de classes, por isso, a busca incessante da classe dominante pelo seu silenciamento (seja ideológico ou físico). Mas, não esqueçam que "somos sementes", com a força das origens que contrariam e alimentam as lutas cotidianas e coletivas que se enchem de inspiração de Dandaras e Zumbis.

Que das favelas venham os novos quilombos com a ginga da capoeira e do samba, da batida do tambor, a inteligência e consciência afiada do Rap, as formas explosivas do grafite, o bailado coletivo do Jongo, as cores vivas das vestes das negras, a delícia da comida boa e farta, o riso solto, o pé no chão, a sabedoria do cultivo e da cura das ervas, a dinâmica do cuidado. Esta força está presente na ocupação viva dos territórios e dessas lições estamos a construir as bases de uma sociabilidade que de forma organizada, pode despontar um verdadeiro território substantivamente livre de despejos, apartheid e guetos. Anunciando, "é tudo nosso", nossa pátria é Palmares!

\section{REFERÊNCIAS}

ABREU, M. H. E. Território, política social e serviço social: caminhos e armadilhas do social-liberalismo. Campinas: Papel Social, 2016.

BRASIL. Constituição Federal (1988). Constituição da República Federativa do Brasil. Brasília, DF: Senado, 1988.

Decreto n. 4.887. Brasília, 20 de novembro de 2003.

ENGELS, F. A questão da habitação. São João Del Rei: Estudos Vermelhos, 2013. 
FARAGE, E. J. Estado, território e cotidiano no Complexo de Favelas da Maré. 2012. . Tese (Doutorado em ) - Universidade do Estado do Rio de Janeiro, Programa de Pós-Graduação em Serviço Social, Curso de Serviço Social, Rio de Janeiro, 2012, 253f.

FERNANDES, F. A revolução burguesa no Brasil. 5. ed. São Paulo: Globo, 2005.

. O negro no mundo dos brancos. 2. ed. rev. São Paulo: Global, 2007.

. Capitalismo dependente e as classes sociais na América Latina.

4. ed. rev. São Paulo: Global, 2009.

FUNDAÇÃO JOÃO PINHEIRO. Déficit habitacional no Brasil 2013: resultados preliminares. Belo Horizonte: 2015. Disponível em: < http://www.bibliotecadigital.mg.gov.br/consulta/consultaDetalheDocumento.php?iCodDocumento $=76698>$. Acesso em: 20 ago. 2020.

GOES, W. L. Racismo e Eugenia no pensamento conservador brasileiro: a proposta de povo em Renato Kehl. São Paulo: LiberArs, 2018.

GOMES. F.S. Mocambos e quilombos: uma história do campesinato negro no Brasil. São Paulo: Claroenigma, 2015.

IANNI, O. Raças e classes sociais no Brasil. 2. ed. Rio de Janeiro: Civilização Brasileira, 1972.

IBGE. Instituto Brasileiro de Geografia e Estatística. Censo Demográfico 2010: Aglomerados Subnormais, informações territoriais. Rio de Janeiro: IBGE, 2013.

. Instituto Brasileiro de Geografia e Estatística. Base de Informações Geográficas e Estatísticas sobre os indígenas e quilombolas para enfrentamento à Covid-19. Notas técnicas. Rio de Janeiro: IBGE, 2020.

JESUS, C. M. Quarto de Despejo: diário de uma favelada. 8. ed. São Paulo: Ed. Ática, 2005.

LEFEBVRE, H. A cidade do capital. Rio de Janeiro: DP\&A, 1999.

MOURA, C. Os quilombos e a rebeldia negra. São Paulo: Brasiliense, 1981. 
Dialética radical do Brasil Negro. 2. ed. São Paulo: Fundação Maurício Grabois co-edição com Anita Garibaldi, 2014.

Sociologia do negro brasileiro. 2. ed. São Paulo: Perspectiva, 2019.

NASCIMENTO, A. O genocídio do negro brasileiro: processo de um racismo mascarado. São Paulo: Perspectivas, 2016.

ROLNIK, R. Guerra dos lugares: a colonização da terra e da moradia na era das finanças. 1 ed. São Paulo: Boitempo, 2015.

ROYER, L. O. Financeirização da política habitacional. São Paulo: Annablume, 2014. 